\title{
CLIMATIC INTERPRETATION OF A CONTINUOUS DEUTERIUM PROFILE OBTAINED FROM THE VOSTOK ICE CORE, ANTARCTICA \\ (160 000 YEARS)
}

\section{(Abstract)}

by

J. Jouzel*, C. Lorius**, J.R. Petit***, C. Genthon*, N.I. Barkov***, Ye.S. Korotkevitch***

and

V.M. Kotlyakov****

* (Laboratoire de Géochimie Isotopique/LODYC, CEA/IRDI/DESICP, DPC-CEN Saclay, 91191 Gif sur Yvette Cédex, France)

** (Laboratoire de Glaciologie et Géophysique de l'Environnement, B.P. 96, 38402 St Martin d'Hères Cédex, France)

*** (Arctic and Antarctic Research Institute, Ul. Beringa 38, 199226 Leningrad, U.S.S.R.)

**** (Institute of Geography, Academy of Sciences of the U.S.S.R., Staromonetnyy 29, 109107 Moscow, U.S.S.R.)

\section{ABSTRACT}

Oceanic studies have convincingly demonstrated that there is a link between the Pleistocene ice ages and the variations in the elements of the Earth's orbit (Imbrie and others 1984). In contrast, the climatic conditions which prevailed over continental areas have been far less well documented and then rarely on a quantitative basis.

In this context, the $2083 \mathrm{~m}$ ice core recovered by the Soviet Antarctic Expeditions at Vostok (East Antarctica) is of fundamental importance because it covers fully the last glacial-interglacial cycle, back to the ice age which preceded the last interglacial ( 160 ka B.P.). Potentially it allows access to many climatic and climate-related parameters as illustrated by the oxygen-18 data we have recently published (Lorius and others 1985), from ${ }^{10} \mathrm{Be}$ measurements (Yiou and others 1985, Raisbeck and others 1987), from aerosol concentration (De Angelis and others 1987) and from $\mathrm{CO}_{2}$ measurement (Barnola and others 1988, this volume).

Our first isotopic data set was largely discontinuous over the last $100 \mathrm{ka}$ (only about $7 \%$ of the core was analyzed), but continuous beyond that time. Sampling of the ice was completed later, in the field, and we now have continuous deuterium data for the whole core (total ice recovery is about $85 \%$ ), combining the data of the $2083 \mathrm{~m}$ core below $138 \mathrm{~m}$ and a complementary data set above. The core chronology was established using a two-dimensional ice-flow model and, for snow accumulation, taking into account change with time (Lorius and others 1985).

There is a general correspondence between this curve and the previously published $\delta^{18} \mathrm{O}$ record (Lorius and others 1985). However, there is obviously far more information in this continuous $\delta D$ record, which we will examine from the deduced temperature record.

\section{THE ISOTOPE TEMPERATURE RECORD}

Several factors may limit the validity of the reconstruction of the local temperature change from the isotope record $\left(\delta^{18} \mathrm{O}\right.$ or $\left.\delta \mathrm{D}\right)$, such as the influence of parameters other than this local temperature, isotopic noise of various origins, and change in ice thickness. Our confidence in such temperature reconstruction for central East Antarctic deep ice cores relies on the following facts:

(1) There is a very well-obeyed linear relationship between the annual averages of the surface temperature and the snow deuterium content over East Antarctica (Lorius and Merlivat 1977).

(2) The observed slope $\left(6 \% /{ }^{\circ} \mathrm{C}\right)$ agrees well with that derived from a one-dimensional isotope model (Jouzel and Merlivat 1984). This model also shows that the $\delta D$ record is less affected by kinetic isotope effects than $\delta^{18} \mathrm{O}$. As these effects are not directly temperature-related, it is suggested that $\delta \mathrm{D}$ rather than $\delta^{18} \mathrm{O}$ be used as the temperature index when both sets of data are available.

Using this $6 \% /{ }^{\circ} \mathrm{C}$ slope, the isotope record was translated into a temperature record after correction for the isotopic changes in sea-water. No corrections were made for the possible influence of the ice origin and changes in thickness of the ice cap. The isotope temperature curve shows that the shift associated with the last deglaciation was around $9{ }^{\circ} \mathrm{C}$. This compares quite well with the $11^{\circ} \mathrm{C}$ change derived independently from crystal-size variation with depth (Petit and others 1987), thus providing independent support for our temperature interpretation. Such independent support also emerges from the good level of agreement between changes in accumulation ratio, derived from the temperature curve and from ${ }^{10} \mathrm{Be}$ data (Yiou and others 1985).

The main features of this isotope temperature curve are the following:

(1) The last deglaciation is clearly a two-step process, with two warming-trend periods interrupted by a $2{ }^{\circ} \mathrm{C}$ temperature reversal lasting about $1 \mathrm{ka}$.

(2) The last glacial complex is characterized by three well-marked temperature minima, with that occurring around 110 ka B.P. being about $2^{\circ} \mathrm{C}$ warmer than full glacial conditions. These cold periods are separated by two interstadials with temperatures up to $4^{\circ}$ and $6^{\circ} \mathrm{C}$ 
respectively above the Last Glacial Maximum (LGM). Conditions equivalent to those prevailing during this LGM were encountered only at the end of the penultimate glacial around $150 \mathrm{ka} \mathrm{B.P.}$

(3) The peak of the last interglacial is significantly warmer than the Holocene period by about $2^{\circ} \mathrm{C}$.

This core offers a unique opportunity to examine from a continental record the link between our atmospheric time series and astronomical forcing. The Vostok spectrum, obtained using the maximum entropy method (MEM), shows concentration of variance around 100,40 and $20 \mathrm{ka}$. This spectral analysis very convincingly demonstrates that, apart from the $\sim 100 \mathrm{ka}$ oscillation, the Vostok temperature record is dominated by a strong $\sim 40 \mathrm{ka}$ component. It also suggests that it is influenced to a lesser degree by a component slightly above $20 \mathrm{ka}$. The two frequency bands can be associated with the obliquity and precession cycles respectively, thus supporting the role of astronomical forcing in determining the Late Pleistocene climate.

\section{COMPARISON WITH OTHER RECORDS}

The Vostok series is compared with time series of the estimated change in continental ice volume and of a Southern Hemisphere sea-surface temperature record: i.e. the stacked SPECMAP $\delta^{18} \mathrm{O}$ record, a proxy of the ice volume, and the estimated summer sea-surface temperature from the very well-documented and geographically relevant sub-polar Indian Ocean core RC11-120 (Martinson and others 1987). For these two series, the chronology established by Martinson and others (1987) stems explicitly from orbital tuning.

The transition from the LGM towards the Holocene takes place around $15 \mathrm{ka}$ B.P. in the three records. Throughout the glacial period, there is generally good correspondence between the three climatic curves, with Vostok cold stages corresponding to marine stages 2, 4 and 5d. The first interstadial corresponds to stage 3 and the second (characterized by two well-marked temperature maxima) corresponds to $5 \mathrm{a}$ and $5 \mathrm{c}$. Down to $110 \mathrm{ka}$ B.P. the correlation between the Vostok and the $\delta^{18} \mathrm{O}$ marine record is excellent $\left(r^{2}=0.87\right)$. As this marine record is thought essentially to represent continental ice-volume changes, i.e. a parameter of global significance, this high correlation indicates that the Vostok temperature record is of relatively great geographical significance.

On the other hand, there is a major difference in the duration of the last interglacial, which is about twice as long in the Vostok record as in the marine record. As the associated climatic changes must be nearly synchronous, this difference is due to discrepancies between the ice and deep-sea core chronologies. Our present strategy is to keep the time-scale of Lorius and others (1985), well established from glaciological arguments, as long as there is no unavoidable argument for modifying it, and to search for a direct correlation between deep-sea cores and the Vostok record among common atmospheric indicators.

In comparison with other deep ice cores, there is good agreement between the three Antarctic records (Byrd Station, Dome C and Vostok) over the last deglaciation and the Holocene period. The temperature shift associated with this transition is around $9^{\circ} \mathrm{C}$ both at Dome $\mathrm{C}$ and at Vostok. Quantitative interpretation of the Byrd Station profile in terms of temperature changes would produce a reasonably comparable value, as the associated $\delta^{18} \mathrm{O}$ shift is similar in the three cores. Again, this supports the great geographical significance of the Vostok record as a whole. As for new dating, relevant information is now available for Dome $C$ and Byrd Station, and the corresponding time-scale for the last glacial may be modified in the near future. Such re-dating must certainly be carried out to determine the closeness of the relationship, and thus the climatic significance of the oscillations registered during this period. Such comparisons between Vostok and Dome C are very promising (Raisbeck and others 1987).

Finally, we also note that in the detailed Vostok curve there is nothing comparable with what has been recorded in the Dye 3, Greenland, ice core (Dansgaard and others 1984), which shows (on the time-scale of a few decades) abrupt and vigorous isotopic changes almost equivalent to those accompanying the Pleistocene-Holocene shift.

\section{CONCLUSION}

We have now obtained a continuous deuterium record along the Vostok ice core, which we have interpreted in terms of local surface-temperature changes over the last $160 \mathrm{ka}$. Comparison with Antarctic records and with the marine record shows that this curve undoubtedly has great geographical significance. The Vostok record is dominated by the large $\sim 100 \mathrm{ka}$ glacial-interglacial oscillation, with a total temperature amplitude of about $11^{\circ} \mathrm{C}$; the long Last Glacial Period is very well documented and it is confirmed that the warmest part of the Last Interglacial Period was about $2^{\circ} \mathrm{C}$ warmer than the Holocene.

It is remarkable that without any radiometric dates or orbital tuning the Vostok temperature record shows concentration of variance near the obliquity and precession frequency band, which strongly supports the climatic role of orbital forcing. This aspect and the influence of other forcings (in particular atmospheric $\mathrm{CO}_{2}$ ) is examined in a companion contribution in this volume (Barnola and others 1988).

\section{REFERENCES}

Barnola J M, Genthon C, Raynaud D, Jouzel J, Korotkevich Ye S, Lorius C 1988 Atmospheric $\mathrm{CO}_{2}$ variations over the last climatic cycle (160000 years), deduced from the Vostok, Antarctica, ice core. Annals of Glaciology 10: 199-200

Dansgaard W and 6 others 1984 North Atlantic climatic oscillations revealed by deep Greenland ice cores. In Hansen J E, Takahashi T (eds) Climate processes and climate sensitivity. Washington, DC, American Geophysical Union: 288-298 (Geophysical Monograph 29)

De Angelis M, Barkov N I, Petrov V N 1987 Aerosol concentrations over the last climatic cycle $(160 \mathrm{Kyr})$ from an Antarctic ice core. Nature 325(6102): 318-321

Imbrie $\mathrm{J}$ and 8 others 1984 The orbital theory of Pleistocene climate: support from a revised chronology of the marine $8^{18} \mathrm{O}$ record. In Berger $\mathrm{A}$, Imbrie J, Hays $\mathrm{J}$, Kukla G, Saltzman B (eds) Milankovitch and climate; understanding the response to astronomical forcing. Dordrecht, D Reidel Publishing Company: 269-305 (NATO ASI Series C; Vol 126, Pt 1)

Jouzel J., Merlivat L 1984 Deuterium and oxygen 18 in precipitation: modelling of the isotopic effect during snow formation. Journal of Geophysical Research 89(D7): 11749-11757

Lorius C, Merlivat L 1977 Distribution of mean surface stable isotopes in East Antarctica; observed changes with depth in the coastal area. International Association of Hydrological Sciences Publication 118 (General Assembly of Grenoble 1975 - Isotopes and Impurities in Snow and Ice): $127-137$

Lorius C and 6 others 1985 A 150,000-year climatic record from Antarctic ice. Nature 316(6229): 591-596

Martinson D G, Pisias N G, Hays J D, Imbrie J, Moore T C Jr, Shackleton N J 1987 Age dating and the orbital theory of the ice ages: development of a high-resolution 0 to 300,000 year chronostratigraphy. Quaternary Research 27(1): $1-29$

Petit J R, Duval P, Lorius C 1987 Long-term climatic changes indicated by crystal growth in polar ice. Nature 326(6108): $62-64$

Raisbeck G M, Yiou F, Bourles D, Lorius C, Jouzel J, Barkov N I 1987 Evidence for two intervals of enhanced ${ }^{10} \mathrm{Be}$ deposition in Antarctic ice during the last glacial period. Nature 326(6110): 273-277

Yiou F, Raisbeck G M, Bourles D, Lorius C, Barkov N I $1985{ }^{10} \mathrm{Be}$ in ice at Vostok, Antarctica during the last climatic cycle. Nature 316(6029): 616-617 